\title{
Global Education in Second Language Teaching
}

\author{
George M. Jacobs and Kip Cates
}

\begin{abstract}
This article paints an optimistic picture of the role we second language teachers can play not only in improving our students' language proficiency but also in infusing global education into our classes as we join with our students to address global concerns, such as peace, prosperity, environmental protection, and human rights. The article is divided into four parts. The first part describes global education and identifies organizations of second language educators participating in global education. The second part of the article focuses on two key areas of global education: peace education and environmental education. Next, we address questions that second language teachers frequently ask about including global education in their teaching. Lastly, we supply lists of print and electronic resources on peace education and environmental education.
\end{abstract}

Keywords: Global education, environmental education, second language teaching methodology, cooperative learning, theme-based instruction, content-based instruction, language across the curriculum, learner-centered instruction, student-generated materials, peace education.

What is your opinion? When you manage to get away from the everyday emergencies of dealing with classes, family, and the other aspects of teachers' lives and look at what is going on in the world, are you optimistic or pessimistic about the future of the human race and of our non-human fellow residents of the planet Earth? Do you believe that we as second language teachers can have any impact on what is going on in the world, or should we concentrate solely on improving our students' language proficiency?

In this article, we two authors propose an optimistic view of the future of this planet. We propose that as our tiny globe spins round the sun, we second language teachers can play a role in making it a better place at the same time that we improve our students' language proficiency. The means by which we have been attempting this lies in the infusion of global education into the second language curriculum.

Our article has four parts. First, we describe what global education entails and provide a list of some organizations of second language teachers who include global education in their teaching. Second, we go into depth on two major areas of global education: peace education and environmental education. Third, we discuss questions that second language teachers frequently ask about the inclusion of global education in their teaching. Finally, we provide lists of print and electronic resources on peace education (Appendix 1) and environmental education (Appendix 2).

\section{What is Global Education}

Global education can be defined as teaching with the aim of empowering students "with the knowledge, skills, and commitment required by world citizens for the solution of global problems" (Cates, 1990: p. 3). Global education covers a wide range of topics. 
One way of categorizing these topics is into four fields: peace education - concerned with reducing violence and with devising peaceful resolutions of conflicts (Reardon, 1988); development education - concerned with deploying sustainable solutions for overcoming poverty (Fountain, 1995); human rights education - concerned with ensuring everyone the freedom to voice their views and to enjoy protection from injustice and discrimination (Shiman, 1993); and environmental education- concerned with defending nature (Greig, Pike, \& Selby (1987).

Too often, global education is thought of as bringing bad news into the classroom, as something that leaves students feeling depressed. No doubt, there is much happening in the world to be sad about, but at the same time, there is much happening to be happy about. Some all-too-familiar examples of the bad news include wars, poverty, racism, endangered species and deforestation, discrimination against women and those of different sexual orientation, injustice, and apathy in the face of all these problems. On the bright side, we can see in the news and in our own lives examples of good news: peace returning to war-ravaged lands, sustainable development lifting people from poverty, people of different races living, working, and learning together harmoniously, protection of endangered species and establishment of protected forests, people working to overcome discrimination and standing up against injustice, and all of this happening because people do care and believe that they can make a difference.

Many second language teachers can be found among the ranks of those trying to make a difference. One way they attempt to have an impact on global issues is via organizations of second language teachers. For instance, the Japan Association of Language Teachers has a Global Issues Special Interest Group (See Appendix 2 for their website address). Other organizations that have similar groups devoted to global education include AILA (International Association for Applied Linguistics), IATEFL (International Association of Teachers of English as a Foreign Language), TESOL (Teachers of English to Speakers of Other Languages), KoreaTESOL, and the World Federation of Modern Language Associations. Further, UNESCO founded Linguapax (http://www.linguapax.org/), an organization that works to put language to the service of peace.

\section{Peace Education and Environmental Education}

\section{Peace Education}

Two scholars from Lebanon, Gaith and Shaaban (1994) present ideas for incorporating peace education in second language instruction. Three aspects of peace education they focus on are themes, skills, and methods. Themes for peace education include: international conflicts, such as wars and trade disputes, and international cooperation, such as people, organizations and governments from various countries working together to work on environmental issues or on developing new medicines from plants; other countries and cultures, so that students can come to know them and appreciate their histories and virtues; cross-cultural communication, so that students understand that people communicate in different ways; and types and roots of violence, e.g., domestic violence, so that students can appreciate that violence does not need to be a part of life.

Skills are a second aspect of peace education that Ghaith and Shaaban suggest fits harmoniously with second language instruction. Of course, the very act of learning a second language plays an important role in bringing about peace, because knowing other 
people's language opens paths toward better understanding and communication. Other skills that peace education and second language education share are those that help people develop the collaborative skills they need to work together, part of which involves skills required to overcome the conflicts that inevitably arise when people work together, such as conflict resolution and peer mediation skills.

Certain teaching methods used in second language education and in education generally that seem particularly suited to peace education are projects, role plays and simulations, and cooperative learning. Projects enable students to spend an extended period of time using their own initiative to go deeply into a particular topic, often one of their own choosing. Further, projects can serve as a vehicle for students to link classroom learning to the outside world and to take actions related to their chosen topic. Role plays (Ladousse, 1987) and simulations (Omaggio, 1978) fit well with peace education, because they encourage students to imagine themselves as different people, in different roles, and/or in different situations, again providing a connection between the classroom and the world beyond.

Cooperative learning can encompass both projects and role plays and simulations, as these usually are done in groups, but cooperative learning represents a wider range of activities in which students work together (Kagan, 1994). Cooperative learning represents a set of concepts and teaching strategies for enhancing the value of studentstudent interaction. Through successful interaction in the classroom, students can develop the skills and attitudes necessary for successful interaction in other spheres and can develop a belief in the power of cooperation (Jacobs, 1998). The fundamental concept in cooperative learning is that of positive interdependence, the feeling among group members that they sink or swim together, that what helps one member helps all and that what hurts one hurts all (Johnson \& Johnson, 1994). Wouldn't the world be a much more peaceful place if we all realized the strong and multiple ways in which we are positively interdependent upon each other?

\section{Environmental education}

The United Nations devised six objectives for environmental education (UNESCOUNEP 1976):

1. Awareness of environmental problems;

2. Basic understanding of the environment and its problems, and humans' role in the environment;

3. An attitude of concern for environmental problems;

4. Skills in overcoming environmental problems;

5. Ability to evaluate proposed solutions to environmental problems;

6. Participation in solving environmental problems.

As a former head of the United Nations Environment Program Ghafoor-Ghaznawi (1993) states, environmental education was conceived as cross-curricular because the environment encompasses all areas of study. Therefore, second language education can play an important role in people learning about and participating in environmental protection. Indeed, Jacobs and Goatly (in press) found that many ELT coursebooks include environmental education themes, such as endangered species, waste minimization, and deforestation. 
However, Jacobs and Goatly report that the UN's sixth environmental education objective, participation, is often lacking from ELT coursebooks' treatment of environmental concerns. This seems particularly problematic, as being aware of environmental problems (objective \#1), understanding why they occur (objective \#2), caring about and having the skills to overcome the problems (objectives \#3 and 4), and being able to evaluate different proposals for addressing them (objective \#5) are all for naught if no action occurs.

While environmental and other global issues can seem overwhelming, many things can be done by individuals and groups of students and teachers. These include: writing letters to governments, organizations, and companies; growing trees and other plants; reducing use of paper, energy, and containers; reusing materials such as glass jars; recycling materials and buying recycled materials, such as recycled paper; educating others and taking part in campaigns to persuade others to participate in environmentally friendly actions; raising funds for environmental causes; and boycotting environmentally unfriendly products, such as those made from endangered species, and instead buying environmentally friendly products, e.g., refrigerators that do not use ozone-depleting chemicals.

When considering participation, we keep these two quotations in mind. The first comes from thinking skills expert Edward de Bono (1998, p. 8), 'If something needs doing, then do something about it. Don't just hope that someone else will. What is everyone's business also has to be someone's business". The other is from Helen Keller who overcame blindness and deafness to become a leading social activist in the early 20th century:

I am only one, but still I am one.

I cannot do everything, but still I can do something.

And, because I cannot do every-thing,

I will not refuse to do the something I can do.

\section{Questions about Integrating Global Education in Second Language Teaching}

A range of questions arise when second language teachers and materials developers attempt to integrate global education. Below, we address four of these questions:

1. Should every lesson be a global issues lesson?

2. Can we teach language at the same time we teach global issues?

3. How can we get enough knowledge about global issues to include them in our teaching?

4. How can we get materials for global education?

\section{Question 1 - Should every lesson be a global issues lesson?}

Infusing global education into second language teaching does not mean every lesson, every reading passage, every group discussion should be about some global concern. What we are advocating is that global education be a regular and consistent part of the curriculum, not just something that is thrown in once or twice a year.

\section{Question 2 - Can we teach language at the same time we teach global issues?}

As Wilga Rivers (1976, p. 96), an authority on second language education since the $1960 \mathrm{~s}$, has written, "As language teachers we are the most fortunate of teachers--all 
subjects are ours. Whatever [the students] want to communicate about, whatever they want to read about, is our subject matter". Indeed, the communicative approach, the dominant one in second language instruction, emphasizes that languages are best learned by using them to communicate meaning, rather than by focusing on explicit learning of grammar and vocabulary. One way of achieving a focus on meaning is via content- or theme-based instruction (Crandall, 1987). Global education provides a wealth of content and themes for students and teachers to choose from.

\section{Question 3 - How can we get enough knowledge about global issues to include them in our teaching?}

As mentioned in the United Nation's environmental education objectives, knowledge is important (objective \#2). However, in a learner-centered education paradigm, the teacher is no longer seen as the key source of knowledge for students. Instead of being 'Sages on stages', we are now "Guides on the side', facilitating learning, helping students discover how they can be independent learners. We are not afraid to say to students, "I don't know. Why don't you find out and teach me and the rest of the class? or "I don't know. How can we find out together?" In addition to gaining knowledge from and with our students, another place to turn is to teachers of other subjects. The increasing popularity of cross-curricular projects offers an excellent way for teachers of different subjects to learn from and with each other as they guide student learning.

\section{Question 4- How can we get materials for global education?}

While some second language coursebooks already contain lessons or parts of lessons related to global education and other ready-made materials can be obtained (see the two appendices for references), these may not be well-suited to our students' immediate needs and interests, or may be too expensive. For materials to be as fresh as today's headlines and closely connected to students' lives, they should be developed at a local or national level. Sources for materials include NGOs, governmental organizations, the media, and businesses. Also, teachers can collaborate with each other to create and share materials. One easy way to create lessons is to take some global issues material, e.g., a simplified version of a newspaper article on solar ovens, and combine it with a technique we like, e.g., Jigsaw (Lie, 1992) in which a reading passage is divided into parts, groups of four or fewer students become experts in one part of the passage and then teach their part to others, after which students take a quiz or do a task based on the entire passage.

Last, but not least, global education materials can be created by students (Deller, 1990; Jacobs, 1993). Among the advantages of student-created materials are:

1. Students may be more motivated, as their level of control and initiative increases;

2. Materials become more relevant to students' backgrounds and interests;

3. Students' may feel greater ownership of what occurs in their classroom, thus enhancing cooperation between teacher and student;

4. Students' anxiety may decrease because they have a role in devising the materials and activities they will be doing;

5. Teachers can gain insights into their students' interests and needs;

6. Learning can increase because creating materials gives students greater insight into the learning process, helping them become more skilful learners;

7. Teachers often lack the funds, equipment, or time necessary for conceiving and producing materials to distribute to all their students; 
8. Teaching becomes more interesting, as variety and surprises take the place of the same textbook year after year.

Among the many ways that students can generate materials are:

1. Bringing in articles or audio/videotapes from newspapers, magazines, radio, tv, and the web (some of these can be found in simplified form, e.g., BBC radio);

2. Recording songs related to global education;

3. Suggesting global education topics related to events taking place where they live, e.g., pollution in a nearby river;

4. Developing questionnaires for coursemates related to global issues; for instance, after students construct and administer a questionnaire related to how environmentally friendly classmates are (e.g., do they carry a cloth bag so they do not collect plastic bags while shopping), the class could make resolutions to adopt more eco-friendly behaviors;

5. Reporting to the class on projects they have done and how their classmates can get involved in the project's global education topic.

\section{Conclusion}

In education, we often do not see the fruits of our efforts until many years later, if at all. We need to have faith that what we are doing will sooner or later help our students become more aware, resourceful, and caring. Global education represents another case in which educators may need to accept delayed gratification. We need to remember the saying, "One generation plants trees, the next generation gets the shade". We cannot solve global problems in a few years. Indeed, they may very well get worse before they get better; all the more reason to keep trying, to keep planting seeds, to keep dreaming of the shade to come.

In this article, we have presented some ideas about how we second language teachers can do our share to educate students in a wholistic way by helping them become better citizens at the same time that they become more proficient in a new language. Implementing these ideas is more difficult that just sticking to the textbook, but our heartfelt experience with our own students tells us that teaching via global issues can be deeply rewarding and satisfying. No doubt, many of you already incorporate global education into your teaching. Please share your good ideas with us and with your other colleagues. We look forward to hearing from you.

\section{References}

Brown, H.D., (1991). 50 simple things you can do to teach environmental awareness and action in your English language classroom. The Language Teacher, 15, 4-5.

Cates, K., (1990). Teaching for a better world: Global issues in language education. The Language Teacher 14: 3-5.

Crandall, J. (Ed.), (1987). ESL through content-area instruction. Englewood Cliffs, NJ: Prentice Hall.

de Bono, E., (1998). Simplicity, London: Penguin. 
Deller, S., (1990). Lessons from the learner: Student-generated activities for the language classroom. London: Longman.

Fountain, S., (1995). Education for development: A teacher's resource guide for global learning. Portsmouth, NH: Heinemann.

Ghaith, F. \& Shaaban, K., (1994). Peace education in the ESL classroom. TESL Reporter, 27/2 Oct 94.

Greig, S., Pike, G., \& Selby D., (1987). Earthrights: Education as if the planet really mattered. London: Kogan Page.

Jacobs, G.M, (1993). The greening of the language classroom: Learner-generated materials for environmental education. Guidelines, 15 (2), 8-17.

Jacobs, G.M., (1998). Cooperative learning or just grouping students: The difference makes a difference. In W.A. Renandya and G.M. Jacobs (eds.) Learners and language learning, pp. 172-193. Singapore: SEAMEO regional language centre.

Jacobs, G.M., \& Goatly, A. (in press). The treatment of ecological issues In ELT coursebooks. ELT Journal.

Johnson, D. W., \& Johnson, R. T., (1994). Learning together and alone (4th ed.). Needham Heights, MA: Allyn and Bacon.

Kagan, S., (1994). Cooperative learning. San Clemente, CA: Kagan Cooperative Learning.

Ladousse, G.P., (1987). Role play. New York: Oxford University Press.

Lie, A., (1992). Jigsaw: Cooperative learning for EFL students. Cross Currents, 19, 4952.

Omaggio, A.C., (1978). Games and simulations in the foreign language classroom. Washington, D.C.: Center for Applied Linguistics.

Reardon, B., (1988). Comprehensive peace education. New York: Teachers College.

Rivers, W., (1976). Speaking in many tongues: Essays in foreign language teaching (2nd ed.). Rowley, MA: Newbury House.

Shiman, D., (1993). Teaching human rights. Denver, CO: Center for teaching international relations.

UNESCO-UNEP. (1976). The Belgrade Charter: A global framework for environmental education. Connect 1/1: 1-9.

\section{Appendix 1 - Peace Education Bibliography}

Compiled by Kip A. Cates, Tottori University, Tottori City, JAPAN 680

Work Tel/Fax: 0857-31-5650, E-mail: kcates@fed.tottori-u.ac.jp

\section{Peace Issues}


Aaseng, N., (1987). The peace seekers: The Nobel Peace Prize. Minneapolis: Lerner Publications.

Barnaby, F. (Ed.), (1988). The Gaia peace atlas. London: Gaia Books.

Humana, C., (1992). World human rights guide. Oxford, UK: Oxford University Press.

Kidron, M. \& Smith, D., (1991). The new state of war and peace atlas. London: Grafton Books.

Keen, S., (1991). Faces of the enemy. San Francisco: Harper Collins.

Stoessinger, D., (1985/1987). Why nations go to war. New York: MacMillan.

Universal House of Justice, (1986). The promise of world peace. London: One World Publications.

Wollman, N (Ed.), (1985). Working for peace. San Luis Obispo, CA: Impact Publishers.

\section{Peace Education}

Arnow, J., (1995). Teaching peace. New York: Perigee Books.

Harris, I., (1988). Peace education. Jefferson, NC: McFarland \& Co.

Hicks, D., Education for peace. London: Routledge, 1988.

Klare, M. (Ed). (1989). Peace and world order studies: A curriculum guide. New York: World Policy.

Merryfield, M. (Ed) (1995). Teaching about international conflict and peace. New York: SUNY Press.

Reardon, B., (1988). Comprehensive peace education. New York: Teachers College Press.

Reardon, B., (1988). Educating for global responsibility. New York: Teachers College Press.

\section{Peace Education Teaching Resources}

Drew, N., (1995). Learning the skills of peacemaking. Jalmar Press, 2675 Skypark Drive, Suite 204, Torrance, CA 90505 USA, Tel: (310) 784-0016 Fax: (310) 7841379

Kreidler, W., (1984). Creative conflict resolution: 200 activities. Glenview, Illinois: Scott Foresman.

Kreidler, W., (1990). Elementary perspectives I: Teaching concepts of peace and conflict. Boston: Educators for Social Responsibility.

Leeds C., (1987). Peace and war: A first sourcebook. Cheltenham, UK: Stanley Thornes. Richardson, R., (1977). World in conflict. Surrey, UK: Nelson. 
Schmidt, F., (1985). Creative conflict solving for kids. Miami: Peace Education Foundation (address below).

Shiman, D., (1993). Teaching human rights. Denver, CO: Center for Teaching International Relations.

Sterling, M., (1992). Thematic unit: Peace teacher materials, Box 1040, Huntington Beach, CA 92647, USA.

\section{Peace Education Organizations}

COPRED (Consortium on Peace Research, Education \& Development), George Mason University, 4400 University Drive, Fairfax, Virginia 22030 USA.

ESR (Educators for Social Responsibility) 23 Garden St. Cambridge, MA 02138, USA.

Institute for Peace and Justice, \#124 - 4144 Lindell, St. Louis, MO 63108, USA Tel: (314) 533-4445.

Peace Education Foundation, 1900 Biscayne Blvd., Miami, Florida 33132-1025 USA Fax: (305) 576-3106.

PEC (Peace Education Commission), c/o Ake Bjerstedt, Box 23501, S-200 45 Malmo, Sweden.

\section{Sample English Language Textbooks On Peace Education Themes}

Akhavan-Majid, R., (1992). Peace for our planet. Tokyo: Kinseido.

Byrne, D., (1984). Mahatma Gandhi - The man and his message. London: Modern English Publications.

Briggs, R. / Strange D., (1992). When the wind blows. London: Penguin.

Brooks, E. \& Fox, L., (1994). Making peace. New York: St. Martins Press.

Jacoby M. \& Marshall, G., (1988). Messages for peace. Tokyo: Kirihara Shoten.

Sorkhabi, R. \& Gillis, A., (1992). A peaceful earth for all. Tokyo: Yamaguchi Shoten.

\section{Peace Education In Language Teaching}

Birch, B., (1992). ESL peaceteachers. TESOL Matters, 23 June/July 1992, USA.

Cunningham, D. (Ed). (1995). Linguapax V. Order from AFMLTA, PO Box 216, Belgrave 3160, Australia.

de Matos, F., (1988). Peace and language learning in TESOL Newsletter Vol. XXII No. 4 Aug. 1988.

Freudenstein, R., (1993). Peace education in the English language classroom in Global Issues in Language Education Newsletter No. 11 July Tottori, Japan. 
Ghaith, F. \& Shaaban, K., (1994). Peace Education in The ESL Classroom. TESL Reporter, Vol 27/2 Oct 94 .

Larson, D. (Ed) (1994). Peace education and TESOL. Idiom . 234 Winter 93/94, NY State TESOL.

Raasch, A. (Ed) (1991). Peace through language teaching. Saarbrucken, Germany: SALUS Press. (Order from Prof. Albert Raasch - address below).

Raasch, A. (Ed) (1993). Language teaching in a world without peace. Saarbrucken, Germany: SALUS Press. (Order from Prof. Albert Raasch - address below)

Raasch, A. (Ed) (1996). Languages: Ways towards peace. Saarbrucken, Germany: SALUS Press. (Order from Prof. Albert Raasch c/o SALUS, Universitat des Saarlandes, Romanistiches Institut, D-66041 Saarbrucken, Germany)

UNESCO. (1987). LINGUAPAX Kiev Declaration: Content and methods that could

contribute in the teaching of foreign languages and literature to international understanding and peace. Paris: UNESCO.

Wenden, A., (1992). "Peace education - what and why?" in TESOL Matters Vol. 2 No. 1 Feb/Mar 1992.

\section{Appendix 2 - Environmental Education Bibliography}

Abramovitz, J.N., (1998). Taking a stand: Cultivating a new relationship with the world's forests. Washington, DC: Worldwatch Institute.

Bang, M., (1997). Common ground: The water, earth, and air we share. New York: Scholastic, [a parable for ages 7 and up]

Bloyd, S., (1990). Animal rights. San Diego, CA: Lucent Books.

Bowers, C.A., (1997). The culture of denial: Why the environmental movement needs a strategy for reforming universities and public schools. Albany, NY: State University of New York Press.

Brown, K., (1998). Air quality today. Surry Hills, NSW: New South Wales Adult Migrant English Service.

Cates, K.A., (1990). Teaching for a better world: Global issues in language education. The Language Teacher 14, 3-5.

Chase, J., (1995). Blueprint for a green school. New York: Scholastic.

Choyce, L., (1995). Big burn. Saskatoon, Saskatchewan: Thistledown Press. [a novel for ages 13 and up]

Cohen, M.J., (1989). The World Peace University field guide to connecting with nature: Creating moments that let earth teach. Eugene, OR: World Peace University.

Consumers Association of Penang. (1997). State of the environment in Malaysia. Penang: Author.

Cornish, S. \& Hood, S., (1994). Troubled Waters, Book 1.Surry Hills, NSW: New South Wales Adult Migrant English Service. 
Cornish, S. \& Hood, S., (1994). Troubled waters, book 2. Surry Hills, NSW: New South Wales Adult Migrant English Service.

Dickenson, P., (1988). Eva. New York: Bantam Doubleday. [a novel for people 12 and up] Earth Works Group. (1991). Kid heroes of the environment. Berkeley, CA: Author.

EarthWorks Group. (1991). The student environmental action guide. Berkeley, CA: Author.

Evans, B., \& Chipman-Evans, C., (1998). How to create and nurture a nature center in your community. Austin, TX: University of Texas Press.

Fleischman, P., (1997). Seedfolks. New York: Harper Collins. [a novel for ages 11 and up]

Goatly, A., (1996). Green grammar and grammatical metaphor. Journal of Pragmatics, $25,537-560$.

Grant, J.E., (1993). The kids' green plan: How to write your own plan to save the environment. Bothell, WA: The Wright Group.

Greig, S., Pike, G., \& Selby, D., (1987). Earthrights: Education as if the planet really mattered. London: Kogan Page.

Hammond, M., \& Collins, R., (1993). One world; one earth: Educating children for social responsibility. Philadelphia: New Society Publishers.

Hirsch, P., \& Warren, C. (Eds.) (1998). The politics of environment in Southeast: Asia: Resources and resistance. London: Routledge.

Hesse K., (1996). The music of dolphins. New York: Scholastic Press. [novel for people 12 and up]

Jacobs, G.M., (1993). Integrating environmental education in second language instruction. Singapore: SEAMEO Regional Language Centre.

Jacobs, G.M., (1995). Developing materials with an environmental focus. In A.C. Hidalgo, D. Hall, \& G.M. Jacobs (Eds.). Getting started: Materials writers on materials writing (pp. 269-279). Singapore: SEAMEO Regional Language Centre.

Jacobs, G.M., Goatly, A., \& Ming, J., (1995). Language and the environment. PASAA, 25, 54-63.

Jacobs, G.M., Kumarasamy, P.M., Nopparat, P. \& Amy, S., (1998). Linking language and the environment. Toronto: Pippin.

Lim, K., (1992). The green age textbook. Singapore: Federal Publications.

Orr, D.W., (1992). Ecological literacy: education and the transition to a postmodern world. Albany, NY: State University of New York Press.

Parnwell, M.J.G., \& Bryant, R.L. (Eds.) (1996). Environmental change in South-East Asia. London: Routledge.

Philippines Department of Education, Culture and Sport, (1998). Hand in hand: Linking environmental education with language learning in the Philippines (4th year supplement). Manila: Author. 
Roberts, E., \& Amidon, E. (Eds.) (1991). Earth prayers from around the worlld: 365 prayers, poems, and invocations for honoring the earth. San Francisco: Harper Collins.

Roszak, T., Gomes, M.E., \& Kanner, A.D. (Eds.) (1995). Ecopsychology: Restoring the earth; healing the mind. San Francisco: Sierra Club books.

Schleppegrell, M.J., (1997). What makes a grammar green? A reply to Goatly. Journal of Pragmatics, 28, 245-248.

Smith, D.C., \& Carson, T.R., (1998). Educating for a peaceful future. Toronto: Kagan and Woo.

Smith, G.A., \& Williams, D.R. (Eds.) (1999). Ecological education in action: On weaving education, culture and the environment. Albany, NY: State University of New York Press.

Steffens, B., (1989). Animal rights: Distinguishing between fact and opinion. San Diego, CA: Greenhaven Press.

Stempleski, S., (1993). Focus on the environment. Englewood Cliffs, NJ: Prentice Hall, 1992.

Strasser, T., Free Willy. London: Penguin.

Tickle, A., (1995). Ecology and the environment: A look at ecosystems of the world. Ann Arbor, MI: University of Michigan Press.

UNESCO-UNEP. (1976). 'The Belgrade Charter: A global framework for environmental education'. Connect, 1(1), 1-9.

\section{Websites}

- Animal Rights Resource Site -- http://envirolink.org/arrs/index.html

- BBC World Service - English Learning Down to Earth: support and stand-alone materials for the 'Down to Earth' English programme on environmental topics: the earth from space, the atmosphere, soil depletion, Gaia theory, sustainable development, conservation for people, green imperialism, poverty, climate change, etc. -- http://www.bbc.co.uk/worldservice/learningenglish/downtoearth/index.htm

- Biodiversity and Conservation Hypertext Book --darwin.bio.uci.edu/ sustain/ bio65/Titlpage.htm

- CCHW: Center for Health, Environment and Justice -- www.essential.org/cchw

- Center for Marine Conservation -- www.cmc-ocean.org

- Center for Plant Conservation -- www.mobot.org/CPC/

- CINTRAFOR (Center for International Trade in Forest Products) -www.cintrafor.org

- Conservation International -- www.conservation.org

- Cultural Survival -- www.cs.org

- Earth Island Institute -- www.earthisland.org

- Earth Share -- www.earthshare.org

- The Earth Times -- www.earthtimes.org

- Earthwatch -- www.earthwatch.org or http:/gaia.earthwatch.org/

- Environmental Defense Fund -- www.edf.org 
- Environmental Education Link -- www.eelink.net/sitemap.html

- The Environmental Education Network -- K-12 Environmental Resources

- on the Internet for Teachers http://www.envirolink.org/enviroed/envirok12.html

- Environmental Journalism -- www.sej.org

- The Environmental News Network -- www.enn.com

- Friends of the Earth -- www.foe.org

- GAIA -- Global Art in Action -- www.globalart.org

- Green Business Letter -- www.greenbiz.com

- Greenpeace -- www.greenpeace.org

- The Green Teacher -- http://www.web.ca/ greentea

- Good Green Fun -- www.efn.org/ dharmika/

- IATEFL Global Issues Web site - http://www.countryschool.com/gisig.htm

- International Alliance for Sustainable Agriculture -- www.mtn.org/iasa

- IUCN -- Forest Conservation Programme -- www.iucn.org

- Japan Association for Language Teaching's Global Issues Special Issues Group -http://langue.hyper.chubu.ac.jp/jalt/nsig/globalissues/gi.html

- The Nature Conservancy -- www.tnc.org

- New Earth Net -- http://nen.sedona.net/

- Pesticide Action Network -- www.panna.org

- Pro-Natura -- www.pronatura.org

- Rainforest Action Network -- www.ran.org

- Rainforest Alliance --http://www.rainforest-alliance.org/

- Resurgence Magazine -- http://www.gn.apc.org/resurgence/

- Saving the Amazon -- worldwildlifefund.org/amazon/

- Sierra Club Foundation -- www.sierraclub.org

- Smithsonian Tropical Research Institute -- www.stri.org

- Student Conservation Association -- www.sca-inc.org

- Sustainable Development Institute -- www.susdev.org

- Union of Concerned Scientists -- www.ucsusa.org

- United Nations Environment Programme -- www.unep.org

- Worldwatch Institute -- www.worldwatch.org

- World Wildlife Fund -- www.worldwildlife.org (also known as WWF or World Wide Fund for Nature) -- http://www.panda.org/ 